\title{
Unpacking the Post-Soviet: Political Legacy of the Tartu Semiotic School
}

\author{
Andrey Makarychev \\ University of Tartu \\ Alexandra Yatsyk \\ Uppsala University
}

\begin{abstract}
This article sketches out general approach to using cultural semiotics as a cognitive tool for analyzing international relations in general and in post-Soviet area in particular. The authors discuss how the homegrown school of cultural semiotics associated with the University of Tartu can be helpful for IR studies. In this respect we place cultural semiotic knowledge in a multidisciplinary perspective and look for projections of its concepts into the vocabulary of foreign policy. Then we intend to discuss the Tartu school from a political perspective, thus claiming that its premium put on cultural issues renders strong politicizing effects. Ultimately, we use cultural semiotic notions and approaches for problematizing the concept of the post-Soviet with its conflictual split between reproducing archaic policies and discourses, on the one hand, and playing by the rules of the post-modern society, with entertainment, hybridity and the spirit of deconstruction as its pivots.
\end{abstract}

Keywords: Post-Soviet transition, cultural semiotics

\section{Introduction}

The discipline of cultural semiotics is peripheral for International Relations (IR) theorizing. Yet it is this peripherality that might bring up new insights in analysis of foreign policies of individual countries and world politics in general, since many political categories (power, borders, security, and even politics itself) can be immensely enriched by meanings derived from a plethora of disciplines that were not in the limelight for IR and its major schools. This is particularly true for the Tartu school of cultural semiotics that was born in the Soviet Estonia, a borderland country that even under the Soviet occupation became a home to worldclass research in this field of social sciences. Semiosphere as a space of multiple meaningmakings is a central concept to this school. Importantly, the cultural semiotic scholarship has grown up at the crossroads of Russia and Europe, which explains its sensitivity to issues of boundaries, communication, identity, inclusion / exclusion, and inside / outside dynamics. This vocabulary remains topical for today's Estonia that in many respects might be regarded as a frontline country - not only according to Huntingtonian lines of civilizational distinction, but also in the framework of a new Cold War between Russia and the West.

Andrey Makarychev, Visiting Professor, Johan Skytte Institute of Political Studies, University of Tartu. Email: andrey. makarychev@ut.ee. Alexandra Yatsyk, Visiting fellow at the Institute for Russian and Eurasian Studies, Uppsala University, Sweden. Email: ayatsyk@gmail.com. 
The Tartu school might be treated as a source of semiotic knowledge and simultaneously a semiotic object itself. It was conceived and matured since the 1950s in Estonia, the most liberal of all Soviet republics. The concepts and ideas developed by the Tartu school are Europe-compatible and even Europe-centric, to which attests a remarkable absence of conceptualizations of the Orient by Yurii Lotman, the founding father of the school, along with other seminal thinkers. In fact, Lotman saw Europe as Russia's key identity maker, thus offering a reverse version of Iver Neumann's vision of Russia - along with Turkey - playing a constitutive role for Europe's identity building in a long historical run.

However, cultural gravitation to - and suture in - Europe is paralleled in Lotman's works with well-pronounced critical attitudes to - and cultural distance from - Europe. This might be explained by the fact that the Tartu school promoters and protagonists stayed in a relative - and sometimes voluntary - isolation from European schools of semiotic analysis, including its French tradition that has significantly enriched IR theorizing through approaching texts as domains of resistance to power, rather than accommodation with it.

In this article we dwell upon a number of core points. We start with a general discussion on how the homegrown school of cultural semiotics associated with the University of Tartu can be used as a tool offering certain optics for IR studies. In this respect we place cultural semiotic knowledge in a multidisciplinary perspective and look for projections of its concepts into the vocabulary of foreign policy. Then we intend to discuss the Tartu school from a political perspective, thus claiming that its premium put on cultural issues renders strong politicizing effects. Ultimately, we use cultural semiotic notions and approaches for problematizing the concept of the post-Soviet with its conflictual split between reproducing archaic policies and discourses, on the one hand, and playing by the rules of the post-modern society, with entertainment, hybridity and the spirit of deconstruction as its pivots.

\section{The Tartu School: A Brief Guide for Political Analysis}

The Tartu tradition of cultural semiotics belongs to what two Estonian scholars dub "Estonian theory as a local episteme - a territorialized web of epistemological associations and rules for making sense of the world" based on academic resources of the University of Tartu. ${ }^{1}$ The Tartu school theorizing is grounded in the idea of semiosphere that is understood as a cultural space where essential meanings are produced, formulated, articulated and communicated. Semiotic studies are interested to find out who and how defines relations of inclusion in and exclusion from the semiosphere, how its boundaries are socially constructed and shaped, and what exactly they delineate? Can cultural borderlands generate their own identities?

For Lotman, centers are self-regulated and relatively well organized entities, and tend to impose their semiotic cores (systems of meanings and norms) to the periphery that often treats these impositions as alien and inappropriate. Boundaries as symbolic and communicative constructs translate foreign cultural narratives into local ones, and thus can be viewed as "membranes" that transform / reprocess the outside into the inside, filter out external cultural impacts and domesticate them. It is due to the existence of cultural boundaries that external spaces get semiotically structured through constructing the outside and ascribing to outsiders certain characteristics that can often be mythical, since what lies on the opposite side of the boundary can easily be culturally marked as "chaotic", "unfriendly", or even "infernal".

' Marek Tamm and Kalevi Kull, "Toward a Reterritorialization of Cultural Theory: Estonian Theory from Baer and Uexkull to Lotman," History of the Human Sciences 29, no. 1 (2016): 75-98. 
Cultural othering (the articulation of self-other distinctions) is thus a central element of cultural semiotics. It is through cultural boundaries that we construct the outer spaces and ascribe to outsiders certain characteristics. Borderlands therefore define the discursively constructed distinctions between "the secure" and "the insecure," "the ordered" and "the disordered," "the allowed," and "the disallowed," which leads to the self-reproduction of a binary type of thinking. Ultimately, the binary structure of discourse leads to "explosion" - a dramatic "collision of misunderstandings" grounded in a conflictual encounter of mutually incompatible and irreconcilable logics.

Many of these semiotic arguments are highly relevant for IR studies. In particular, it would be fully consistent with Lotman's theorizing to argue that Russia and Europe, two political communities-in-the-making, discursively construct each other's role identities, and are in the process of a painful of bargaining over their boundaries and adjusting to policies of each other. The binary logic often prevails in this process: in spite of all attempts to get rid of the Cold War legacy, the structure of EU-Russia communication reproduces and reinforces the logic of binary oppositions. Besides, this process of mutual / reciprocal construction leaves both Russia and Europe undetermined as to properly defining their (common) neighborhood(s), of which Ukraine seems to be the most dramatic example.

\section{Cultural Semiotic School as a Homegrown Theory}

There might be different approaches to tackle homegrown theories and engage with them in theorizing international relations. In this section we discuss how the Tartu School is relevant to improving the extant IR theoretical platforms such as constructivism and post-structuralism The cultural semiotic reading of international relations inspired by the Tartu school raises a couple of particular issues that we would like to touch upon in this section, namely related to the multidisciplinary potential of the school and a problem of translating its key terms into other conceptual languages.

\subsection{From the Tartu school to social constructivism and post-structuralism}

Multidisciplinarity: The indispensability of interdisciplinary analysis for IR can be well illustrated by tracing intellectual trajectories of basic political concepts, such as power, security, borders, etc. At certain point of maturation all of them have became open to various readings that infused into these concepts cultural, sociological, anthropological and other interpretations and vistas. Due to this interdisciplinary cross-fertilization many traditional concepts were deployed in denser cultural and discursive contexts. Thus, the idea of security became problematized from the viewpoint of discursive practices of securitization and desecuritization, politics is discussed in terms of the interconnected processes of politicization and depoliticization, boundaries and frontiers are viewed through the prism of bordering and debordering as social and cultural phenomena, etc. Today's academic discourse in many IR domains is replete with interdisciplinary language - security cultures, biopower, identity, otherness, and so forth.

We may start integrating the cultural semiotics into various IR theories and schools with finding some similarities between them. There are indeed many overlapping approaches and interpretations that form a vast area for cross-theoretical discussions.

Semiotics in many respects is close to social constructivism with its self-other dynamics and emphasis on collective identity making. The constructivist social ontology claims that 
ideational structures trump material ones. Therefore, analysis of actors' policies should start not with the allegedly pre-existing interests (as realists would do), but with social roles chosen by actors within a certain cultural milieu. "It is through communication - usually discursive, but also ritual and symbolic - that ideational structures condition actors' identities and interests, ${ }^{2}$ both constructivists and semioticians would consent. They would also agree that norms are a structural phenomenon, or "a means to maintain social order"3. In other words, norms are not simply instruments that states utilize at their liking; they foster changes in behavior, identities, and then interests of international actors. Thus, in constructivist reasoning, structures have prior causal power over agents. ${ }^{4}$ Semioticians would definitely second this claim, explaining that it is deep mechanisms of culture that in each society are foundational for its semiosphere and thus play a systemic role in its maturing.

The structural approach espoused by constructivism implies that social reality represents a network of invisible connections that compose a variety of social fields. Alexander Wendt has cogently captured this point by arguing that structures not only constrain but, more importantly, construct agents. What should be added to this point is the characterization of structures as "containers" of hegemonic relations. As Jonathan Joseph rightly presumed, "hegemony acts as a crucial mediating moment in the relation between structure and agency... [Hegemony thus] reaches down to the structural issue of the reproduction of the social formation and the various structural ensembles...Hegemony comes to represent the political moment in the structure-agency relation". 5

In the meantime, some elements of cultural semiotics might be compatible with the post-structuralist theorizing. Cultural semioticians might find a particularly rich common language with the school of critical discourse analysis when it comes to language games, imitation, mimicking and other discursive strategies widely applied by international actors in communicating with each other.

By the same token, cultural semiotic input might be quite substantial for studies of regionalism and, in particular, for the conception of boundaries as generators of important social, cultural and political dynamics. Yurii Lotman is known for his keen interest in semiotic analysis of boundaries in many cultural contexts. Post-positivists regionalist scholars would argue that "borders are moving apart - as exemplified by the history of Europe over the centuries". ${ }^{6}$ Therefore, political and legal borders of nation states less and less coincide with the complex patterns of social life, they believe. More specifically, a meeting point of semioticians and regional scholars could be a discussion on typology of boundaries that might include:

- "Borders" as geographical lines/zones that separate two territorial entities;

- "Frontiers" requiring a certain policy towards something what lies beyond them;

- "Edges" and "peripheries," synonymous with underdevelopment, instability and

2 Christian Reus-Smit, "Reading History through Constructivist Eyes," Millennium: Journal of International Relations 37, no. 2 (2008): 406.

Antje Wiener, "Constructivism: The Limits of Bridging Gaps," Journal of International Relations and Development 6, no. 3 (2003): 253 .

4 Petr Drulak, "The Problem of Structural Change in Alexander Wendt's Social Theory of International Politics," Journal of International Relations and Development 4, no. 4 (2001): 307.

5 Jonathan Joseph, "Hegemony and the Structure-Agency Problem in International Relations: A Scientific Realist Contribution," Review of International Studies 34, no. 1 (2008): 130.

Zdravko Mlinar, ed., Globalization and Territorial Identities (Brookfreld, Vermont: Avebury, 1992), 26.

Noel Parker, "Integrated Europe and Its 'Margins': Action and Reaction," in Margins in European Integration, ed. Noel 
exposure to external dangers. Political and cultural geographers describe peripheries as remote outskirts, or outlying - and usually fragmented - territories with obliterated features, and areas heavily dependent upon policies of pivotal powers;

- "Margins" that are not only products of core powers, but exist in two-way relations with these powers. ${ }^{8}$ Margins usually have room to maneuver and a meaningful degree of freedom in exploiting the advantages of their location. Politically, margins might be reluctant to accept that the core speaks for them; moreover, they may define the nature of the core itself. Culturally, regional identities are believed to be dependent upon interrelations between central and marginal entities.

According to post-structuralist regional scholars, state boundaries cannot bind or limit these new types of activities (in political, ecological, economic, religious, cultural, ethnic, or professional domains). The world thus is undergoing a transition from territorial communities (including nation-states) to "networks" that are independent of specifically defined territorial foundations and national identities. Networks blur distinctions between "insiders" and "outsiders", as described by the concept of "open geography" (as opposed to the idea of "inescapable geography"). ${ }^{9}$ Open geography posits that "geographical cardinal points are relative", ${ }^{10}$ and that there are no strict dividing lines between regions which are understood as mobile social and cultural constructs that might "encounter," "clash," "inject their own stories," etc. ${ }^{11}$ This seems to be very much in line with Yurii Lotman's and Vladimir Toropov's ${ }^{12}$ approaches to St. Petersburg as a particular type of text that is constitutive for Russian historical and cultural narratives. The "Petersburg text" is structurally close to what is currently known as "popular geopolitics" - a type of vernacular knowledge about geographical interpretations of political issues based on people's narratives, myth, peformances, spectacles, rumors, and even anecdotes. The "Petersburg text," as seen from the cultural semiotic perspective, is composed of a multitude of literary representations of this city that belongs to the cultural spaces of Russia and Europe simultaneously, is included in and excluded from Europe, and within Russia balances between two reputations - as representing Russian identity and as being culturally exceptional, if not alien to Russian cultural mainstream.

This is an important point that can be extended further on by arguing that there can be no single mode of spatial representation or articulation of spaces, and all spatial arrangements can be opposed by alternatives. ${ }^{13}$ Geography cannot lock up regions in a "steel cage," and geographical affiliations are subject to re-writing and re-interpretation. ${ }^{14}$ Therefore, both cultural semiotics and post-structuralism offer a decentralized, network-oriented model of the world, which leaves space open for creativity, inspiration, and the force of imagination, which is harmonious with approaches developed by cultural semiotics.

8 Christopher Browning and Pertti Joenniemi, "Contending Discourses on Marginality: the Case of Kaliningrad" (working paper, Danish Institute for International Studies, Copenhagen, 2003).

9 Colin Gray, "Inescapable Geography," The Journal of Strategic Studies 22, no. 2/3 (1999): 161

${ }^{10}$ Carl-Einar Stalvant, "The Northern Dimension: A Policy in Need of an Institution?" (BaltSeaNet working papers 1, Nordeuropa-Institut der Humboldt-Universität, Berlin, 2001), 5.

${ }^{11}$ Pertti Joenniemi and Marko Lehti, "On the Encounter Between the Nordic and the Northern: Torn Apart but Meeting Again?" (working paper 36, Copenhagen Peace Research Institute, Copenhagen, Denmark, 2001), 32-3.

12 V.N.Toropov, "Peterburg i 'Peterburgskiy tekst' russkoi literatury (vvedenie v temu)," in Mif. Ritual. Simvol. Obraz: Issledovania v oblasti mifopoeticheskogo. Izbrannoe, ed. V.N. Toropv (Moscow: "Progress" Publishers, 1995), 259-367.

${ }_{13}$ Mathias Albert, "From Territorial to Functional Space: Germany and the Baltic Sea Area" (working paper 39, Copenhagen Peace Research Institute, Copenhagen, Denmark, 2000), 10-3. 22-3.

${ }^{14}$ Evaldas Nekrasas, "Is Lithuania a Northern or Central European Country?" Lithuanian Foreign Policy Review 1 (1998): 
There might also be a strong semiotic contribution to security studies, especially when it comes to the concept of securitization. Neither Lotman nor his disciples directly touched upon issues of risks, threats and dangers, yet the contemporary debates on ontological (in) security, as related to the vulnerabilities of collective identities, appear open to semiotic inputs. It is semiotic approach that can be helpful for elucidating a number of important aspects of the debate in this academic domain.

First, the debate on the discursive nature of security construction initiated by the Copenhagen school has been extended to the sphere of imageries and visuals. This trajectory fully corresponds to the evolution of the Tartu school that initially was exclusively textand language-centric, yet ultimately matured into a more comprehensive field of studies to incorporate films, fashion, music and performative arts.

Secondly, a semiotic gaze might be productive for identifying voices of (in)security beyond the group of power holders. Opening up the sphere of politics to a variety of cultural phenomena, semioticians can be instrumental in explaining the roles of cultural actors (managers, producers, performers, authors, artists, etc.) in shaping the public agenda that defines perceptions of security.

Thirdly, the centrality of communication for semiotic relations might lead the contemporary followers of the Tartu school to a conceptually important rejection of taking the audience of security discourses as a pre-established and well-structured social group. In its stead, Lotman's legacy might be interpreted in the sense that it is through the process of verbal interaction between "producers" and "consumers" of security narratives that both groups discursively construct their identities and subjectivities. ${ }^{15}$ However, given the linguistic (speech act-based) nature of the process of securitization, security-making can presumably be a self-referential practice, as opposed to an inter-subjective one. ${ }^{16}$ In other words, when it comes to existential security and survival, the space for dialogic communication tends to shrink, and the dominant discourse is usually bent on self-assertion and, as semioticians would say, autocommunication, rather than on dialogue.

Fourthly, there are some meaningful parallels between conceptualizing boundaries of the security sphere and boundaries of the semiosphere. Some security experts raised an important question of whether "security can mean everything," 17 and tend to answer it affirmatively, implying that each element of social and physical reality can be securitized, from water supply to language. A similar discussion takes place within the community of cultural semioticians as well: many of them claim that the semiosphere can embrace everything; yet in the meantime certain elements of material and ideational reality can be deprived of semiotic characteristics and thus relegated to the a-semiotic domain. The question is thus what exists beyond the semiosphere, and what segments of reality can be discursively excluded, discarded, ignored, rejected, denied or bracketed out as allegedly semiotically irrelevant and even non-existent, only because they disturb the seeming cohesiveness of the dominant discourse? Is there something for which we don't have a language of conceptualization, and which therefore stays beyond representation? In particular, cultural semiotics and security studies can find

${ }^{15}$ Matt McDonald, "Securitization and the Construction of Security," European Journal of International Relations 14, no. 4 (2008): 563-87.

16 Thierry Balzacq, "The Three Faces of Securitization: Political Agency, Audience and Context," European Journal of International Relations 11, no. 2 (2005): 177.

${ }^{17}$ Felix Ciuta, "Security and the Problem of Context: A Hermeneutical Critique of Securitization Theory," Review of International Studies 35 (2009): 301-26. 
a common language in exploring perceptions and remembrances of traumatic experiences (wars, ethnic cleansings, cases of genocide, etc.) as an important element of the discursive making of security.

Translation: We may continue incorporating cultural semiotics into the terrain of international studies with an operation known from Lotman's works as translation, or projecting the established semiotic concepts into the languages pertinent to other disciplines, such as IR.

One example would be the projection of the concepts of the sign and the image onto the domain of soft power, which opens interesting research perspectives. In fact, soft power is a deeply semiotic concept, since it can't be operational beyond the semiosphere as the space where meanings are produced and communicated. The focus on the semiotic core of soft power allows seeing that "words alone often cannot carry the power that they often have the force of affect is needed to explain how words resonate with audiences and have political effects beyond their mere verbal utterance... There is no 'natural' link between words and the objects, identities, and so on that they purport to express...The attachment of signifiers to signified... is dependent upon an affective push prompting the construction of this linkage". ${ }^{18}$ This approach is of particular importance for soft power studies since it allows treating attraction as a largely performative and cultural construct that exists only under the condition of symbolic and emotional investment in it.

Another example is the reconceptualization of a rather traditional notion of cultural interdependence (for example, between Russia and Europe) into the post-structuralist idea of the suture that denotes the phenomenon of impossibility to break away from someone/ something that you might wish to distance from. The suture is an intricate metaphor that describes the complexities of the inside - outside interrelations and dynamics. To quote Slavoj Zizek, the suture means that "self-enclosure is a priory impossible, that the excluded externality always leaves its traces within". ${ }^{19}$ The suture denotes "a mode in which the exterior is inscribed in the interior" to the point of erasing substantial differences and forming "a consistent, naturalised, organic whole." However, the suturing of external reality is always incomplete, and "external difference is always an internal one, ${ }^{\prime 20}$ which demonstrates an inherent impossibility for the sutured political subject "to fully become itself". ${ }^{21}$ This is exactly what can be used for comprehending a key controversy of the various regionmaking projects aimed at creating a coherent and prosperous regional society, distinct from the insecure outside; yet it is the irreducible and inassimilable otherness that leaves "the decentred traces" inside the regional societies-in-the-making. In particular, Lotman's analysis of the precarious status of Russia as a European actor and its Other that needs to be domesticated nicely reflects the duality of the suturing process.

\subsection{Political dimensions of cultural semiotics}

Our next step would be to discover the wider political utility of approaching international relations from a cultural semiotic perspective. The question to be discussed is how the Tartu Schools can offer more novel approaches to IR studies. $720-30$

18 Ty Solomon, “The Affective Underpinnings of Soft Power," European Journal of International Relations 20, no. 3 (2014):

19 Slavoi Zizek, The Fright for Real Tears: Krzysztof Kieslowski between Theory and Post-Theory (London: BFI Publishing, 2001), 58.

${ }^{20}$ Zizek, The Fright for Real Tears, 57.

${ }_{21}$ Zizek, The Fright for Real Tears, 58. 
Hereby the concept of the sign - as consisted of the signifier and the signified - seem to be crucial. It is the arbitrary linkage between the two elements that creates the space for political interventions, impositions and manipulations. In other words, without investments in producing and interpreting signs, that is to say relating signifiers with signifieds, politics can't properly function.

In the meantime, the discipline of cultural semiotics offers good academic lens for exploring the process of re-signification, or redeployment of terms in previously unexplored or even "unauthorized" contexts. Re-signification is mostly used by agents located at the margins of political structures who wish to change previous meanings by either expanding the scope of concepts or by including other meanings into them. ${ }^{22}$ Re-signification is closely related to language games. Following the logic of Wittgenstein, language has neither ontological stability nor unity; consequently, there is no authoritative, determinate collective "we" that would appeal to a mental or metaphysical source of identity or authority, or unveil "literal, uninterpreted truth". ${ }^{23}$ The language games approach claims that each concept under a closer scrutiny decomposes into a series of "pictures" of reality with their "playful and fluid" 24 contexts. We shall come back to this while discussing the post-modernist reading of the post-Soviet Russia.

One should also pay attention to cultural semiotics as a helpful tool in discovering different languages of (international) politics. For example, instead of binary distinction between democracy and autocracy the discipline of cultural semiotics prefers to speak about different types of discourses, with a key distinction between dialogue (inter-subjective communication) and auto-communication (or self-referential communication), requiring no external other for legitimizing its speaking positions. In this sense the semiotic approach can be instrumental in avoiding absolutization and universalization of inter-subjectivity as one of pillars of constructivist theorizing; from a semiotic perspective inter-subjective construction of each other's identities might be challenged or reversed by more unilateral and even unidimensional discourses grounded in the radiation of meanings from one center to multiple peripheries.

Very close to that we may find the semiotic concept of autopoiesis. "If the human mind is an autopoietic system, i.e. one that permanently constructs its own world, then representation can only be self-referential in nature. Self-reference has, furthermore, been declared to be a characteristic feature of postmodern culture. If postmodernity is confronted with a loss of the referent of the signs... the remains of these signs thus deprived of their function of representation can only become self-referential". ${ }^{25}$

The most important political conclusion from the semiotic approach to culture is that value-based discourses increase the chances for auto-communication, both in democracies and non-democracies. Semiospheres can be playgrounds for totalizing practices, which explains the dangers of self-description and self-referentiality: the semiosphere can become "a self-identical homogenous structural whole" with a consequent effacement of internal

22 Birgit Schippers and Judith Butler, "Radical Democracy and Micro-politics," in The Politics of Radical Democracy, ed. Adrian Little and Moya Lloyd (Edinbourgh, UK: Edinburgh University Press, 2009), 80-91.

${ }^{23}$ Christopher Robinson, Wittgenstein and Political Theory: The View from Somewhere (Edinbourgh, UK: Edinbourgh University Press, 2009), 12-3.

${ }^{24}$ Robinson, Wittgenstein, 49.

${ }_{25}$ Winfred Noth, "Crisis of Representation?" Semiotica 143, no. 1/4 (2003): 13. 
differences and multiplicity"26 through discursive practices of totalization, internalization, centring and structural unity that are manifested in a universalized language with a "single finite truth" that "occupies the core of the semiotic space" and "functions as the basis of what Lotman defines as the transcendental unity of self-consciousness" ${ }^{27}$ It is exactly at this point that "a central codifying mechanism appears as a kind of generator of transcendental signifiers which are imposed as universal expression forms into the different contents circulating within the semiotic space, and which transforms the latter into an ordered and hierarchical totality". ${ }^{28}$

From a policy perspective, it is exactly this semiotic frame that might be used for understanding the unexpected for most analysts upsurge of far-right, conservative, nationalist, nostalgic and global-sceptical discourses all across the West, especially against the backdrop of the refugee crisis. These discourses that struggle for hegemony not only within specific countries (France, Germany, Austria, Poland, etc.), but also within the West, can be qualified as self-referential, autocommunicative and autopoietic in the sense that its bearers do not seek recognition or legitimation through constructively and interactively engaging with alternative or opposing discourses; rather they stabilize themselves through grounding in the idea of self-sufficiency of national forms of identification and reinterpretation of traditional Western concepts of democracy and freedom.

\section{A Cultural Semiotic Perspective on the Post-Soviet Space}

The theoretical observations given above might be used for purposes of political analysis in the sphere of post-Soviet studies, with Russia as the key player in this respect. In this section we focus on a range of possible interpretations of the post-Soviet space from a cultural semiotic perspective, which might be enriching for understanding the logic of turbulent transition in this part of the world.

In the extant literature much has been said about archaic and retrospective - if not retrograde - nature of many of post-Soviet regimes. This is particularly the case of Russia whose post-Soviet identity is largely rooted in practices vectored to the bygone past - great power management (otherwise known as a concert of great powers), spheres of influence, balance of power, etc. There are many voices in Russian academic community describing Russia as an archaic type of society that challenged rationality in decision-making and accumulates potential for coercion and violence. ${ }^{29}$ The rehabilitation of the Soviet model plays a particularly salient role in the archaic shift. What has started as basically a commodification and commercialization of nostalgia ${ }^{30}$ in a matter of years became a powerful source of politicization. According to Sergey Naryshkin, the head of the External Intelligence Service, Russia should not apologize for its history whatsoever. ${ }^{31}$ Elements of the Soviet semiotics came gradually back, ${ }^{32}$ including, for instance, the restoration of Leonid

26 Daniele Monticelli, Wholeness and Its Remainders: Theoretical Procedures of Totalization and Detotalization in Semiotics, Philosophy and Politics (Tartu: Tartu University Press, 2008), 194.

27 Monticelli, Wholeness and Its Remainders, 195.

28 Monticelli, Wholeness and Its Remainders, 194

29 Uliana Nikolaeva, "Grozit li Rossii novoe srednevekovie," Nezavisimaya Gazeta, October 25, 2016, http://www.ng.ru/ stsenarii/2016-10-25/9_6843_middleages.html.

${ }^{30}$ Karen Gazarian, "SSSR v obiortke ot konfety," Gazeta.ru, September 12, 2015, http://www.gazeta.ru/ comments/2015/09/06_a_7742285.shtm.

31 "Naryshkin: Rossiya ne dolzhna kayatsa za svoyu istoriyu," RIA-Novosti, June 17, 2013, http://ria.ru/ interview/20130617/943689762.html\#ixzz2WT51eWWG.

32 “Sovetskaya antichnost v datakh i kartinkakh," Profil, November 13, 2015, http://www.profile.ru/politika/item/101253- 
Brezhnev's commemorative plaque in Moscow. ${ }^{33}$ The Minister of Culture claimed that the society should praise the Soviet heroes as the Church venerates its saints; ${ }^{34}$ in its turn the head of the Russian Orthodox Church declared that one should not belittle achievements of Stalin. ${ }^{35}$

This nostalgic trend definitely stretches far beyond Russia. The case in point is not only Russia's increasingly obvious penchant for recycling Soviet practices; what is more, intellectual departures and recipes from the Cold War times (from the Kennan "long telegram" to Henry Kissinger's advices to today's Russian leaders) still keep their vitality and validity as explanatory tools applicable to a new reality of Russia's confrontation with the West that obviously challenges ideas of globalization, trans-nationalization and de-territorialization constituted at the core of the post-Cold War international normative order.

It is not only that the Cold War mentality is easily revivable under this semiotic frame, but also the legacy of the Second World War can be recycled, as illustrated by the projection of the anti-fascist discourse of the time of the Great Patriotic War onto the situation in today's Ukraine. These domestic trends have their foreign policy implications, since they can explain why Russian political establishment seriously considers "to play the same game as before [with the West], but to play it smarter". ${ }^{36}$

The semiotic dimension is crucial for duly comprehending this dominant tendency of building today's Russian foreign policy on the highly symbolized and glorified triumphalist models excavated from the collective memory. It would be fair to assume that with the generation of wartime veterans almost completely passed away, the pro-Stalinist sentiments of certain social groups are based on the desire to identify themselves with a demonstration of force as such. ${ }^{37}$ The repetitive emotional rereading of the Great Patriotic War and the emotional projection of its meanings to contemporaneity are key elements of Russian security discourses under Putin's presidency, especially in the aftermath of the annexation of Crimea. ${ }^{38}$ The fight against fascism during the Second World War became a major reference point not only in the Russian mainstream discourse justifying the land grab by protecting ethnically Russian people from the so called "Kyiv's junta," but also in Russian performative propaganda that is an interesting object of semiotic research. One of the most illustrative examples is a bike show staged by the explicitly pro-Kremlin group "Night Wolves" near Sebastopol after the annexation: its plot visually represent the Maidan revolution as a neoNazi coup masterminded by the West and aimed against both Ukraine and Russia, which justifies Russia's interference paralleled with the Soviet mission in the 1941-1945 war with fascism. ${ }^{39}$

\footnotetext{
sovetskaya-antichnost-v-datakh-i-kartinkakh.

${ }_{33}$ Pavel Chernomorsky, "V Moskve vosstanovyat memorial'nuyu dosku na dome Brezhneva," Slon, May 27, 2013, http://slon. $\mathrm{ru} /$ fast/russia/v-moskve-vosstanovyat-memorialnuyu-dosku-na-dome-brezhneva-946056.xhtml.

${ }^{34}$ Vladimir Medinsky, "Iz vsekh iskusstv vazhneishim dlia nas yavliaetsa istoriya," Rossiyskaya Gazeta, August 26, 2015, https://rg.ru/2015/08/26/pravda.html.

${ }_{35}$ Andrey Arkhangel'skiy, "Primirenie so zlodeistvom. Pochemu Patriarkh govorit ob uspekhakh pri Stalinizme," Slon, November 9, 2015, https://republic.ru/posts/59277.

${ }^{36}$ Maxim Trudolyubov, "Putin: a Soviet Leaders for the 21 Century," The Moscow Times, March 18, 2015, http://www. themoscowtimes.com/opinion/article/putin-a-soviet-leader-for-the-21st-century/517646.html.

${ }^{37}$ Lev Gudkov, "Derealizatsiya proshlogo: funktsii stalinskogo mifa," Pro et Contra, November - December 2012, http:// carnegieendowment.org/files/ProEtContra_57_108-135.pdf.

${ }_{38}$ Irina Kosterina and Sergei Ushakin, "My u proshlogo ne uchimsia, my im zhiviom," Neprikosnovenniy zapas 4, no. 102 (2015): 161-81.

39 "Bike Show - 2014. Sevastopol. Culmination," YouTube video, 35:31, from a performance recorded on August 9, 2014, 
From a semiotic viewpoint, the recycling of Soviet experiences might be seen as a major boost for a binary type of thinking, particularly salient in times of security crises, which leaves at the limelight of discourse "only overt contrasts, only direct meanings, no metaphors". ${ }^{40}$ This semiotic reading leaves much space for drawing some - perhaps unexpected - parallels between Lotman and Carl Schmitt. Lotman's interpretation of the deep structures of Russian culture as grounded in polarizing binaries is coterminous with Schmitt's understanding of the structure of the political as firmly engrained in the friend-foe dichotomy. ${ }^{41}$ Andreas Schonle and Jeremy Shine ${ }^{42}$ rightly claim that binary oppositions can be helpful for solidifying the hegemonic discourses and preventing them from fragmentation and dissipation, and it is exactly this political function that seems to be dominant in the case of Russian foreign policy's resemblance - if not continuity - with Soviet practices and experiences.

Yet there is a different - and much less studied - dimension of the Putin regime, namely its ability to engage with more complex foreign policy models. To a large extent, Putin's hegemonic discourse displayed a great deal of agility in deeply engaging with the manipulative potential of discourses and imageries grounded in the cultural industry producing signs and symbols, as exemplified by speech acts and images used for both consolidating the regime from inside and conveying a set of essential messages for external audiences. It might thus be argued that one of explanations of Putin's regime is its appropriation of meaningful semiotic resources that it deploys in discursive contexts that delegitimize the kernel of the Western normative order. It is in this sense that this strategy can be considered as part of post-modernist paradigm that celebrates "the liberation of signs from dependency on welldefined signifieds... [and] from the strict confines of normative, foundationalist doctrines, ${ }^{43}$ and it is this semiotic reality that Putin's hegemonic discourse uses for the sake of stabilizing itself. This reality also includes the exhaustion and fading away of grand narratives. The strategy of the Kremlin foreign propaganda is exactly grounded in taking advantage of the "end of ideology" that is instrumentalized and pragmatically, if not cynically, turned against the core normative commitments of the West. Russia's foreign policy messages are packed not as a consistent discourse, but as clusters of "catchphrases", "codes without referents" that simulate "a reality where even the original turns out to be a mere copy" ${ }^{44}$

The blurred boundaries between the fact and the fiction, and the de-facto substitution of politics with performative acts of "post-truth" indicate a much greater problem stretching beyond Russia, since they might be seen as symptoms of a new worldview that excludes predictability, negates rationality, and downplays the attempts to judge the present from the standpoint of historical experience accumulated since the collapse of communism. Putin's project, therefore, can be seen as a part of post-modern deconstructions: unlike the Soviet project, it does not need to emanate the ultimate truth, in its discursive milieu everything is potentially constructed and deconstructed, with blurred lines between the fake and the real. At this juncture, cultural semiotics might offer a particularly interesting research outlook

${ }^{40}$ Andrey Pertsev, "Nichego smeshnogo. Kak patrioticheskiy renessans stior granitsy parodii i real'nosti," Slon, February 12, 2015, https://slon.ru/russia/nichego_smeshnogo_kak_patrioticheskiy_renessans_ster_granitsy_parodii_i_realnosti-1214827.xhtml.

${ }_{41}$ Carl Schmitt, The Concept of the Political (Chicago \& London: The University of Chicago Press, 2007).

42 Andreas Schonle and Jeremy Shine, "Introduction," in Lotman and Cultural Studies: Encounters and Extensions, ed. Andreas Schonle and Jeremy Shine (Madison: The University of Wisconsin Press, 2006), 10.

${ }_{43}$ Mark Gottdiener, Postmodern Semiotics: Material Culture and the Forms of Postmodern Life (Oxford and Cambridge: Blackwell, 1995), 233.

${ }^{44}$ Noth, "Crisis of Representation?," 9-15. 
from a post-structuralist perspective of "society of the spectacle" (authored by Guy Debord) and simulacrum (developed by Jean Baudillard), concepts with strong semiotic backgrounds. Today governments and corporate actors invest huge budgets in creating systems of signifiers (nation branding, place promotion, high-profile performances and shows, cultural and sportive mega-events, etc.) that not only embellish undemocratic rule, but often distort and misrepresent the situation on the ground. This is especially the case of authoritarian governments looking for legitimizing their policies through investing in symbolic capital and using propagandistic imageries and visuals aimed for domestic and external consumption. Non-Western regimes are quite successful in promoting their semantically loaded messages and signs, however detached from reality they might be. Their discourses and imageries can be quite adaptable to the post-industrial information society of the $21^{\text {st }}$ century. Some of these regimes in the post-Soviet area, Russia included, use the whole global infrastructure of media entertainment and advertisement for legitimizing their rule through cultural association with Europe that otherwise is lambasted as a source of morally inacceptable and socially detrimental practices. As many authoritarian regimes, Russia invests in promoting and legitimizing itself through what might be called a political economy of performances, images and regimes of signification. As many other countries, it is eager to spend lots of resources for the sake of advertising itself and embellishing its image for global audiences. Sportive mega events are a particular form of cultural production of entertainment, a series of exorbitantly expensive mega signifiers for nation branding and advertisement. The Sochi Olympics was an important element of politically legitimizing the Putin regime through selfassertive discourses of national pride, respect and admiration.

\section{Conclusions}

One of major conclusions to be drawn from this analysis is a huge - and still unexplored emancipatory potential of semiotic expertise as a contributor to IR (re)theorizing. We have seen that many of well established IR concepts can be treated as semiotic constructs (such as soft power), and in the meantime many semiotic terms (representations, signs and meanings, etc.) can be read from the vantage point of IR scholarship. This intellectual cross-fertilization might open up the discipline of cultural semiotics to wider inter- and multi-disciplinary exposures, and by the same token discover cultural underpinnings in the professional lexicon of IR specialists.

An important element of our analysis concerns the culture-politics debate. Pace Lotman's initial insistence on the autonomy of culture as inherently apolitical (or extra-political) sphere, many of the post-Lotman scholars specifically focus on political dimensions of cultural practices. As we have argued in this article, the fundamental political aspect of semiotic (and thus sign-based) representations, both textual and visual, boils down to the arbitrary and changeable nature of relations between the signifier and the signified; in other words, in the possibility to always reconsider and remold the meanings we attach to concepts as cornerstones of our language. (Re)signification therefore is pivotal for the everlasting process of (re)producing the political momentum, which from a practical perspective is a powerful tool for any politically meaningful action - socialization, mobilization, manipulation, and so forth.

One more facet of semiotic analysis relates to its contribution to elucidating the structure of political discourses. Of particular relevance is Lotman's acceptance of deep dependence 
of our thinking on dichotomies, followed by his anticipation of the transformation of the dominant binary logic into a more complex ternary one. Indeed, many of primordial political and academic conceptualizations are formulated in the language of binary distinctions - such as friends versus enemies, "false Europe" and "true Europe" (Iver Neumann's conception of two dominant paradigms of Russia's western policies), bordering and debordering, securitization and desecuritization, etc. A good example at this point would be a binary soft-hard security distinction that reflected primarily the dominant Western attitudes and anticipations in the immediate aftermath of the end of the Cold War, when other dichotomies were in a wide use as well (democracy versus autocracy, or freedom versus non-freedom).

One of the problems at this point is that many of these binaries have lost their cognitive potential and political appeal, since the structure of international relations has gradually become more complex and less susceptible to simplistic divisions and partitions. In a post-modern type of discourse binaries can be viewed as largely irrelevant and lacking in explanatory force; however many of them appear quite resilient and still keep playing their structuring roles in many political discourses, especially those positively retrospective (including the neo-Soviet nostalgia in the post-Soviet Russia addressed above, or the European right-wing sympathies with "old good times" of the nation state).

The debate on the power of binaries and their endurance can be extended to the analysis of the internal nature of the polarized structures. In particular, a distinction can be drawn between intersubjective dialogue between the two opposing poles (for example, proponents of hard versus soft security), and the autocommunicative and self-referential mode of articulation within each of the poles. The latter is conducive to the appearance and proliferation of concepts that position themselves as relatively self-sufficient and disinterested in legitimizing their discursive power through constant referring to and engaging with alternative or competing sources of conceptualization. In the sphere of IR - as in other social sciences - this leads to the dominance of rather closed schools of thought with their specific language of communication and circle of devoted adherents. This is why breaking invisible barriers between schools and theories and reaching out to other disciplinary fields is one of the most topical issues for interdisciplinary academic research.

From a semiotic perspective it would be also expedient to pay attention not only at the divisive momentum inherent in binary concepts, but also in their roles as building blocs in constructing relations of equivalence, with potential political consequences. For example, discourses that equate - or, at least, place at the same grounding - Communism and fascism as two forms of totalitarian dictatorships trigger ardent protest from the official Moscow that insists on treating them as historical mortal enemies fighting against each other. A similar political mechanism of equalization is manifested in a vision of Russian propaganda representing a challenge as strong to the EU as that of ISIS $^{45}$. Obviously, from the Russian perspective, Islamic terrorist groups are a common enemy of both Russia and the West, which is meant at creating a completely different relation of equivalence and difference.

These examples attest to an intricate nature of self-other (or "us" -versus- "them") distinctions indispensable for any identity making. The cultural and semiotic production of relations of otherness and alterity necessarily implies both polarization (along with

45 "MEPs sound alarm on anti-EU propaganda from Russia and Islamist terrorist groups," European Parliament News, November 23, 2016, http://www.europarl.europa.eu/news/en/news-room/20161118IPR51718/meps-sound-alarm-on-anti-eupropaganda-from-russia-and-islamist-terrorist-groups 
distinction and partition) and construction of equivalence (or relations of solidarity and positive association). This symbiotic intermingling exposes one of the pivotal elements of politicization as a series of speech acts grounded in cultural and semiotic identification and dissociation, alignment and disengagement.

Semiotic analysis can be immensely helpful in scrutinizing cultural underpinnings of political momenta and their interpretations in categories stretching far beyond approaches traditional to political science and IR. The cultural semiotic toolkit, leaving aside simplistic binaries, looks at cultural contexts of political actions and practices through focusing on their performative, aesthetic and artistic dimensions not as peripheral, but rather as central elements of the political. It is in this capacity that the discipline of cultural semiotics might find its niche in bringing new creative insights in analysis of foreign policy and international relations.

\section{Bibliography}

Albert, Mathias. "From Territorial to Functional Space: Germany and the Baltic Sea Area." Working Paper 39, Copenhagen Peace Research Institute, Copenhagen, Denmark, 2000.

Arkhangel'skiy, Andrey. "Primirenie so zlodeistvom. Pochemu Patriarkh govorit ob uspekhakh pri Stalinizme." Slon, November 9, 2015. https://republic.ru/posts/59277.

Balzacq, Thierry. "The Three Faces of Securitization: Political Agency, Audience and Context." European Journal of International Relations 11, no. 2 (2005): 171-201.

Browning, Christopher, and Pertti Joenniemi. "Contending Discourses on Marginality: the Case of Kaliningrad." Working Paper, Danish Institute for International Studies, Copenhagen, 2003.

Chernomorsky, Pavel. "V Moskve vosstanovyat memorial'nuyu dosku na dome Brezhneva." Slon, May 27, 2013. http://slon.ru/fast/russia/v-moskve-vosstanovyat-memorialnuyu-dosku-na-dome-brezhneva-946056.xhtml.

Ciuta, Felix. "Security and the Problem of Context: A Hermeneutical Critique of Securitization Theory." Review of International Studies 35 (2009): 301-26.

Drulak, Petr. "The Problem of Structural Change in Alexander Wendt's Social Theory of International Politics." Journal of International Relations and Development 4, no. 4 (2001): 363-79.

Gazarian, Karen. "SSSR v obiortke ot konfety." Gazeta.ru, September 12, 2015. http://www.gazeta.ru/ comments/2015/09/06_a_7742285.shtm.

Gottdiener, Mark. Postmodern Semiotics: Material Culture and the Forms of Postmodern Life. Oxford and Cambridge: Blackwell, 1995.

Gray, Colin. "Inescapable Geography.” The Journal of Strategic Studies 22, no. 2/3 (1999): 161-77.

Gudkov, Lev. "Derealizatsiya proshlogo: funktsii stalinskogo mifa.” Pro et Contra, November - December 2012. http://carnegieendowment.org/files/ProEtContra_57_108-135.pdf.

Joenniemi, Pertti, and Marko Lehti. "On the Encounter Between the Nordic and the Northern: Torn Apart but Meeting Again?” Working Paper 36, Copenhagen Peace Research Institute, Copenhagen, Denmark, 2001.

Joseph, Jonathan. "Hegemony and the Structure-Agency Problem in International Relations: A Scientific Realist Contribution." Review of International Studies 34, no. 1 (2008): 109-28.

Kosterina, Irina, and Sergei Ushakin. "My u proshlogo ne uchimsia, my im zhiviom." Neprikosnovenniy zapas 4, no. 102 (2015): 161-81.

McDonald, Matt. "Securitization and the Construction of Security." European Journal of International Relations 14, no. 4 (2008): 563-87.

Medinsky, Vladimir. "Iz vsekh iskusstv vazhneishim dlia nas yavliaetsa istoriya." Rossiyskaya Gazeta, August 26, 2015. https://rg.ru/2015/08/26/pravda.html.

Mlinar, Zdravko, ed. Globalization and Territorial Identities. Brookfreld, Vermont: Avebury, 1992. 
Monticelli, Daniele. Wholeness and Its Remainders: Theoretical Procedures of Totalization and Detotalization in Semiotics, Philosophy and Politics. Tartu: Tartu University Press, 2008.

Nekrasas, Evaldas. "Is Lithuania a Northern or Central European Country?” Lithuanian Foreign Policy Review 1 (1998): 19-45.

Nikolaeva, Uliana. “Grozit li Rossii novoe srednevekovie.” Nezavisimaya Gazeta, October 25, 2016. http://www. ng.ru/stsenarii/2016-10-25/9_6843_middleages.html.

Noth, Winfred. “Crisis of Representation?” Semiotica 143, no. 1/4 (2003): 9-15.

Parker, Noel. "Integrated Europe and Its 'Margins': Action and Reaction.” In Margins in European Integration, edited by Noel Parker and Bill Armstrong, 3-27. Basingstoke, Hants: Macmillan Press \& St.Martin Press, 2000.

Pertsev, Andrey. "Nichego smeshnogo. Kak patrioticheskiy renessans stior granitsy parodii i real'nosti." Slon, February 12, 2015. https://slon.ru/russia/nichego_smeshnogo_kak_patrioticheskiy_renessans_ster_granitsy_ parodii_i_realnosti-1214827.xhtml.

Reus-Smit, Christian. "Reading History through Constructivist Eyes." Millennium: Journal of International Relations 37, no. 2 (2008): 395-414.

Robinson, Christopher. Wittgenstein and Political Theory: The View from Somewhere. Edinbourgh, UK: Edinbourgh University Press, 2009.

Schippers, Birgit, and Judith Butler. "Radical Democracy and Micro-politics." In The Politics of Radical Democracy, edited by Adrian Little and Moya Lloyd, 73-91. Edinbourgh, UK: Edinburgh University Press, 2009.

Schmitt, Carl. The Concept of the Political. Chicago \& London: The University of Chicago Press, 2007.

Schonle, Andreas, and Jeremy Shine. "Introduction." In Lotman and Cultural Studies: Encounters and Extensions, edited by Andreas Schonle and Jeremy Shine, 3-35. Madison: The University of Wisconsin Press, 2006.

Solomon, Ty. "The Affective Underpinnings of Soft Power." European Journal of International Relations 20, no. 3 (2014): 720-41.

Stalvant, Carl-Einar. “The Northern Dimension: A Policy in Need of an Institution?” BaltSeaNet Working Papers 1, Nordeuropa-Institut der Humboldt-Universität, Berlin, 2001.

Tamm, Marek, and Kalevi Kull. "Toward a Reterritorialization of Cultural Theory: Estonian Theory from Baer and Uexkull to Lotman.” History of the Human Sciences 29, no. 1 (2016): 75-98.

Toropov, V.N. "Peterburg i 'Peterburgskiy tekst' russkoi literatury (vvedenie v temu)." In Mif. Ritual. Simvol. Obraz: Issledovania v oblasti mifopoeticheskogo. Izbrannoe, edited by V.N. Toropv, 259-367. Moscow: "Progress" Publishers, 1995.

Trudolyubov, Maxim. "Putin: a Soviet Leaders for the 21 Century." The Moscow Times, March 18, 2015. http:// www.themoscowtimes.com/opinion/article/putin-a-soviet-leader-for-the-21st-century/517646.html.

Wiener, Antje. "Constructivism: The Limits of Bridging Gaps." Journal of International Relations and Development 6, no. 3 (2003): 252-75.

Zizek, Slavoi. The Fright for Real Tears: Krzysztof Kieslowski between Theory and Post-Theory. London: BFI Publishing, 2001. 
